Artigos

Daniele Borges Bezerra

(UFPel)

Juliane Conceição Primon

Serres (UFPel)

\title{
Memorial José Avelino: Um lugar de memória para iluminar memórias invisíveis
}

\section{INTRODUÇÃO: CONTEXTUALIZANDO O CAMPO DE ESTUDO}

Neste artigo nos propomos a apresentar uma discussão teórica sobre memória e imagem na qual introduzimos o problema das memórias traumáticas a partir do caso da Colônia Santa Izabel, considerado um lugar de memória do campo da saúde, que dispõe, no centro de seu conjunto histórico, do Memorial José Avelino, um dispositivo memorial criado por ex-moradores, que reúne, preserva e expõe um acervo constituído por objetos e fotografias, vestígios da vida no interior do isolamento sanitário.

O antigo hospital Colônia Santa Izabel foi criado na década de 1920 para receber pessoas diagnosticadas com lepra. Atualmente denominado Casa de Saúde Santa Izabel e localizado em Betim, Minas Gerais, a uma hora da capital, o local atende, ainda hoje, cerca de 300 ex-moradores remanescentes do período de internação compulsória, e teve alguns de seus prédios tombados pelo órgão de patrimônio histórico e cultural de Betim no ano 2000. O crescimento da comunidade do entorno da Colônia Santa Isabel foi tanto, ao longo dos anos, que: “hoje se alguém chegar lá, sem saber da história, nem sabe que já foi uma colônia" (Flores 2016).

A lepra, chamada apenas no Brasil de hanseníase (com o objetivo de reduzir o preconceito associado à doença e facilitar o diagnóstico precoce e a adesão ao tratamento de novos casos o termo lepra foi substituído por hanseníase em 1995, conforme a Lei no 9.010, de 29 de março), é uma doença bacteriana, infectocontagiosa, de dimensão planetária, associada a situações de pobreza, que ainda possui uma grande incidência sobre a população brasileira e, portanto, se constitui como um problema de saúde pública. A transmissão ocorre por meio das vias respiratórias, com o contato com secreções nasais e saliva de pessoas infectadas pelo bacilo de Hansen que ainda não tenham iniciado o tratamento. É 
uma doença de progressão lenta, que pode levar de dois a cinco anos para se manifestar, e que acarreta lesões neurológicas que afetam principalmente a pele e os nervos ópticos e periféricos, provocando deformidades. Contudo, com o tratamento disponível atualmente, a evolução da doença é interrompida, evitando-se sequelas. Os esforços no campo da saúde são no sentido de detectar possíveis recidivas e identificar os novos casos para que a doença seja eliminada. Hoje em dia, o tratamento poliquimioterápico (PQT) é doado ao Brasil pela Organização Mundial da Saúde (OMS) e disponibilizado pelo Sistema Único de Saúde (SUS). O tratamento é ambulatorial, e o portador deixa de ser um transmissor em potencial já a partir da primeira dose da medicação.

Contudo, nem sempre foi assim. No início do século XX, ainda não havia um tratamento efetivo para a doença no Brasil, e o crescimento dos casos de lepra representava um problema de saúde pública. Com isso, criou-se um serviço de profilaxia da lepra que adotou a política de internação compulsória dos pacientes, por período indeterminado, em hospitais-colônia.

As mais de trinta instituições criadas em todo território nacional entre as décadas de 1920 e 1940 , seguiam um modelo norueguês de construção, sendo organizadas na forma de microcidades. A primeira delas, que começou a funcionar após a extinção da Inspetoria de Lepra e Doenças Venéreas, foi a Colônia do Prata, no Pará, fundada em 1924 no antigo território indígena dos Tembé. A doutoranda Rosani de Fatima Fernandes (2015), orientada pela doutora Jane Beltrão, que desenvolveu várias pesquisas na chamada região do Prata, destaca a característica corretiva da construção, que inicialmente tinha o objetivo de catequizar os Tembé e que durante um ano serviu como colônia penal, antes de ser designada para abrigar o primeiro leprosário nacional. O hospital-colônia Lazarópolis do Prata foi fundado pelo médico Heráclides César de Souza Araújo, referência no estudo da lepra no Brasil.

A área das antigas colônias era dividida em três zonas: zona sadia (onde ficavam as casas dos médicos, diretor, administrador e funcionários), zona intermediária (formada pelos prédios da administração, da padaria, a casa das irmãs, o pavilhão de observação...) e a zona suja (onde ficavam pavilhões, enfermarias, escolas, forno de incineração, necrotério, oficinas, cemitério...) (Morhan 2010). No interior da colônia, na zona destinada aos doentes, havia uma estrutura com praças, cinema, cancha de futebol, teatro, padaria, escola, entre outros. A escola possuía uma divisão por gênero e oferecia conteúdo escolar correspondente aos três primeiros anos do ensino fundamental. Essa organização visava atender às necessidades coletivas básicas de qualquer cidadão e permitir que os internos produzissem seus próprios bens de consumo, sem precisar sair dos limites do hospitalcolônia, tal como o modelo de "instituição total” discutido por Erving Goffman (2003:16).

Para impedir as fugas, esses hospitais eram localizados em pontos estratégicos, isolados geograficamente e de difícil acesso, muitos fazendo fronteira com rios ou lagoas que dificultavam a saída. Outro ponto de destaque eram as moedas próprias que algumas colônias possuíam, impedindo que os fugitivos tivessem algum poder de consumo fora do interior da colônia. Cada colônia possuía uma cadeia, onde eram punidos os moradores que infringissem a lei interna da colônia. Eram consideradas infrações uma tentativa de fuga ou pegar na mão da namorada, por exemplo. 
Segundo relatos de moradores, no caso da Colônia Santa Izabel, em Betim, Minas Gerais, havia guaridas em volta da área do hospital-colônia, onde um guarda destacado dentre os próprios moradores impedia que as correntes fossem ultrapassadas. Foi apenas em 1962, com a circulação dos discursos de cura, que o Decreto do Conselho de Ministros no 968, de 07 de maio, determinou que os pacientes internados de modo compulsório passassem a ter o direito de se deslocarem para além dos domínios da colônia. Contudo, segundo relatos de moradores, as correntes só "caíram" mesmo em Santa Izabel na década de 1980. Ainda no sentido de desconstruir o pavor social instituído sobre a doença, o Decreto n ${ }^{\circ}$ 10.040, de 25 de julho de 1977, do Estado de São Paulo, alterou o termo lepra para hanseníase, com o objetivo de reduzir o preconceito historicamente associado à contaminação e ao pecado.

Durante a imersão em campo que permitiu a redação deste trabalho, a fotografia permeou o percurso de pesquisa juntamente com a história oral e gerou uma cartografia do lugar em aproximadamente 600 imagens, que registram a presença das pessoas nos espaços de circulação da Colônia Santa Izabel, assim como as alterações geradas pelo crescimento do bairro Citrolândia, que englobou o antigo hospital. As fotografias realizadas possibilitam o retorno mental do pesquisador e a reativação de memórias do período de imersão no campo. Além disso, acredita-se que a fotografia e o texto se complementam na fase de apresentação dos resultados, pois existem coisas que não podem ser narradas e outras que são mais bem visualizadas pelas imagens do que pela escrita.

Com relação aos princípios éticos implicados na pesquisa, destaca-se que os autores têm a autorização firmada pelos interlocutores para a utilização das imagens. Com relação aos nomes, todos optaram por ser identificados pelos seus nomes reais, o que reforça um desejo de participação no centro da história desses lugares.

\section{RESTOS E SIGNOS DE EXPERIÊNCIAS INDIZÍVEIS: UMA EXPERIÊNCIA ÉTICO-MORAL ENTRE EMPATIA E IMAGINAÇÃO}

Estar diante de uma pessoa que teve hanseníase no período em que não havia tratamento, alguém que teve uma progressão violenta da doença, é uma experiência delicada. Entrar em contato com o sofrimento do outro requer um exercício de empatia. É necessário desconstruir o estigma que relaciona o sofrimento físico a falhas de caráter, como se a lepra fosse um tipo de "encarnação do mal". Esse estigma foi construído e reforçado por signos como a matraca, instrumento preso ao braço utilizado no período medieval para identificar, com o som produzido, o doente que se aproximava. Com a criação de lugares de isolamento ocorreu também um silenciamento, que começa a ser rompido meio século depois. Não restam dúvidas de que a metáfora da lepra como doença moral precisa ser desconstruída, e Sontag já chamava a atenção para o fato em 1984. Nesse sentido, acreditamos que não basta substituir o termo "lepra" por "hanseníase", como ocorreu no Brasil, pois a doença segue sendo a mesma, o que mudou foi a compreensão sobre esta ao longo do tempo e, com isso, a eficácia do tratamento. Nesse sentido, a batalha contra a lepra não é apenas pela identificação e pelo tratamento precoce do bacilo. É, sobretudo, contra a metáfora da doença, investida de estigmas que perpassam o corpo físico por meio do social. 
Durante o trabalho de campo, no encontro com pessoas que viveram o isolamento, as narrativas eram como a apresentação das suas feridas de guerra, pois a experiência de exílio sanitário requereu uma relação de enfrentamento da doença em nível físico e simbólico. A narrativa de Nelson Flores deixa claro o encontro/ confronto/ conflito direto com o problema, na tentativa de superar as perspectivas apresentadas pelo exemplo de outros internos que padeceram no interior das colônias, sem tratamento adequado:

Quando eu acabei de pagar o meu tratamento, eu fiquei feliz demais. Foi uma vitória na minha luta. A maior vitória que eu tive na minha vida, porque eu queria viver a doença - eu aceitei ela e suas consequências - mas deixar me vencer eu não queria. [...] Eu nunca deixei a doença me atropelar. No livro' você vai encontrar essa frase: 'ou eu morreria deprimido pelo complexo como tantos companheiros dentro da colônia ou eu partia pro meu mundo livre'. [...] Eu superei a doença, o obstáculo que ela me impunha, e busquei o meu mundo livre, sem medo. (Flores, N. Betim, Belo Horizonte, 2016).

Essa dimensão da luta, desencadeada a partir do próprio corpo, desloca o sofrimento de uma possível localização externa, na qual o isolamento seria o responsável, e localiza-o como evento individual, personalização da doença. Nessa tentativa de controle do próprio destino, a pessoa recusa uma condição de vítima passiva e reincorpora uma dimensão do poder sobre o seu arbítrio, pois passa a investir com esperança no propósito de superação da doença e do isolamento. Parece-nos que a luta, no presente, que responde ao fim do silenciamento, é revelar o ser humano que vive "com" e "apesar" das consequências da doença. Essa luta equivale à superação de uma ferida aberta, em sentido simbólico, tal como o proposto por Susan Sontag (2003) no livro Diante da dor dos outros.

Dedicado a uma reflexão sobre o efeito das imagens de sofrimento e a exposição de imagens dolorosas no curso da história, como algo que pode ser naturalizado pelo excesso de exposição, este livro propõe a questão: como cessar de naturalizar o sofrimento do outro de modo espetacular? Como desnaturalizar o sofrimento? Se pensarmos na maneira massiva como somos bombardeados por imagens de todo tipo, podemos pensar, tal como o cineasta Wim Wenders, no documentário Janela da alma (2001), que o excesso de estímulos visuais que recebemos, uma espécie de poluição visual, nos impede de ver a não ser através de molduras que determinam um foco.

Assim, vivemos entre milhares de fotografias (mentais, impressas ou digitais), envenenados pela mídia com uma enxurrada de imagens, e, gradativamente, cada uma delas passa a ter menos importância. Estamos como Funes, o memorioso (Borges 2007: 104), em um "mundo entulhado": "olhava sem ver, ouvia sem ouvir, esquecia-se de tudo, de quase tudo", adoecidos pelo excesso, incapazes de guardar ou gerir novas memórias. Walter Benjamin também fala desses "sintomas" como produtos da "cultura do choque", da banalização das imagens no cotidiano; o excesso generalizante que desfigura o sujeito social ao enquadrar as formas de vida e cria personagens marginais, como o flâneur (Benjamin s/d: 185). E é nesse deambular caótico, em meio a uma enxurrada de imagens naturalizadas, enquadramentos e distorções produzidos socialmente, indexados pela cultura da absorção passiva, que acabamos por nos chocar diante de coisas que nos são inerentes, como as enfermidades, e a naturalizar o que deveria produzir choque, como a violência. 
Barthes afirma que "a fotografia é subversiva não quando assusta, perturba ou até estigmatiza, mas quando é pensativa" (Barthes 2010: 47). Assim, o objetivo da pesquisa que levou à escrita deste artigo não foi o de expor a dor do outro, reforçar seu sofrimento ou vitimizar quem viveu, mas compreender como essas memórias podem ser transmitidas sem ferir a ética. Almejamos aprofundar nossa compreensão sobre um universo de memórias, seus lugares de fixação e transmissão, tal como Roland Barthes percebe sua abordagem em relação à fotografia: "não como uma questão (um tema), mas como uma ferida: vejo, sinto, portanto reparo, olho e penso". (Barthes idem: 30$)$.

Nesse sentido, a fotografia, integrada à história oral, à pesquisa documental e à análise de discurso, cumpre um objetivo comum a antropólogos e fotógrafos, tal como sugerido por Etienne Samain a respeito da utilização da fotografia em pesquisa: a fotografia responde à mesma "necessidade de dizer o homem" (1995: 27). Ao propor uma historiografia da antropologia da imagem, Etienne Samain chama atenção para o fato de que, apesar da preponderância da escrita nos trabalhos de cunho antropológico e de certo desconhecimento sobre o lugar da antropologia da imagem enquanto método científico, a fotografia nunca desempenhou uma mera função de ilustração.

Em 1914, quando começou seu trabalho de campo na Melanésia, Malinowski já percebia a necessidade de uma comunhão metodológica entre fotografia e escrita. Para Etienne Samain, a pesquisa com imagens contribui para uma "arte do saber ver e uma arte do poder dizer e do fazer pensar através de imagens" (Samain, idem). Acredita-se na qualidade pensante da imagem, tal como proposto por Etienne Samain, discípulo de Lévi-Strauss e Bateson, com quem aprendeu que mais importante que descobrir o "porquê" das coisas é saber o "como". Portanto, interessa-nos pensar com as imagens, a partir delas: "quais são suas maneiras de nos fazer pensar?" (Samain 2012: 21).

Para introduzir esta discussão sobre fotografia e imagem, propõe-se uma reflexão sobre a necessidade que temos de materializar nossas experiências. Basta estarmos atentos para perceber que nossas lembranças se apoiam em quadros sociais e vivem em imagens (Halbwachs 2006). Desde muito cedo fazemos uso das imagens enquanto signos. Atribuímos significados às experiências, simbolizamos, organizamos e objetificamos essas experiências de modo espontâneo e involuntário. As imagens estão desde cedo imbricadas aos elementos imateriais envolvidos nos processos cognitivos, afetivos e sensoriais diretamente vinculados à formação e à evocação das memórias. Quando um menino de cinco anos afirma: “Fiquei com aquela música na cabeça. Mas eu não consigo cantá-la. Tem um rádio tocando lá", percebe-se que as imagens participam do processo de assimilação das experiências intangíveis, do incorpóreo, daquilo que diz respeito aos fenômenos e aos sentidos, e também dos "indizíveis".

Embora seja possível considerar a fotografia impressa como um objeto, a qualidade fenomenológica da imagem que resulta na fixação de algo que não é mais, "a imagem viva de uma coisa morta" (Barthes 2010: 89) faz com que a fotografia seja compreendida como uma "epifania", tal como proposto pelo antropólogo Etienne 
um mergulho atrelado à própria capacidade do pensamento, pois a fotografia é associativa, além de narrativa. Como afirmava Barthes (2010), ela é a prova de que "isto foi" e de que o fotógrafo presenciou aquilo que está fixado sob a forma de imagem.

De modo ambíguo, a fotografia é um gesto de seleção e, ao mesmo tempo, contingência, e é isso que faz com que a fotografia atue no campo dos fenômenos como um recordatório de caráter quase sagrado, com certa vitalidade sobre as emoções. Esse aspecto sagrado deve-se à emanação aurática que vincula o instante único de um objeto fotografado no passado a alguém que o vê registrado no presente. Além disso, a fotografia possui a qualidade de ser um marcador do tempo que passa, mesmo sem situá-lo. Seja pelo registro de um objeto ausente, seja pelo registro das alterações da matéria que registra e, por fim, das degradações que ela mesma sofre no tempo, tanto numa impressão no papel quanto na forma de um arquivo corrompido ao qual não temos mais acesso no HD, a fotografia não cessa de lembrar-nos da passagem do tempo.

Em se tratando de dispositivos de preservação da memória, de modo semelhante, alguns objetos parecem ter a capacidade de nos tornar sensíveis a eventos ou pessoas do passado e, de alguma maneira, emanar seus referentes enquanto duram. Essa capacidade de emanação do referente, contudo, é relativa e depende dos usos e interpretações dados aos objetos no presente. Independentemente da "forma" expositiva do acervo de um museu, de seu discurso subliminar e da composição daquilo que se pretende transmitir, ou seja, além do desejo original de preservação e transmissão, existem diversas formas de se relacionar com aquilo que está sendo mostrado.

Os objetos assumem um valor de documento capaz de apresentar elementos do passado e fornecer subsídios memoriais e jurídicos que ampliam o presente, ao mesmo tempo em que são investidos de uma missão de futuro. Ao tratar da qualidade documental dos objetos, entendidos como suportes de informação histórica, Ulpiano Menezes afirma que "qualquer objeto pode funcionar como documento e mesmo o documento de nascença pode fornecer informações jamais previstas em sua programação" (Menezes 1998:95), mas esta qualidade dos objetos não lhes é imanente, está sempre sujeita à participação de um terceiro, externo a ele. Cabe, portanto, ao pesquisador ou ao visitante do museu identificar nos objetos os seus sentidos históricos ou memoriais. Na qualidade de arquivo, exprimem uma responsabilidade para com o futuro e, tal como a fotografia, possuem uma "messianidade espectral que atravessa o conceito de arquivo e o liga, como a religião, como a história, como a própria ciência, a uma experiência muito singular da promessa" (Derrida 2001: 51).

Essa messianidade do arquivo também está presente na fotografia, que a partir da fixação do vivido gera um tipo de ilusão sobre a permanência. O que Philippe Dubois, a partir da lógica indicial associada ao ato fotográfico, chama de "matar o tempo", uma forma de "memória detida" (Dubois 2012: 163). Para Barthes, as fotografias não rememoram o passado, "a fotografia tem algo a ver com ressurreição", como o "Sudário de Turim" (Barthes 2010: 93). Ou seja, "a foto é literalmente uma emanação do referente [...] liga o corpo da coisa fotografada ao meu olhar" (Barthes 2010: 91). E aí está a ambiguidade da fotografia, que, ao mesmo tempo em que afirma a presença: "isto foi" (idem), também testemunha a passagem do tempo e declara "a vulnerabilidade de vidas que rumam para a própria destruição". 
As fotografias transformam-se em "fantasmagorias de papel" (Sontag 2004: 85). Ou, como afirma o antropólogo Mauro Guilherme Koury, são "a morte colecionada e transformada em vida real" (Koury 1996: 4). Para o autor, a fotografia cumpre uma função de simulacro e representa um legado do passado, um "consolo" para a ausência. Nessa presentificação do passado, a partir da fotografia "o passado da relação torna-se o passado registrado, apagando arestas, sofrimento, rancores e realçando positividades, cumplicidades e companheirismos" (Koury idem), de modo que a fotografia, enquanto registro (e artefato) é reformada, a partir do trabalho de memória dos dias, e é apropriada como agente de recordação fotográfica.

Basta pensar nas tantas lembranças que temos de infância, sobre cujo desenrolar dos eventos não temos objetividade, nossas lembranças estão, muitas vezes, ancoradas nos registros fotográficos do momento. Registros vistos, revistos e narrados centenas de vezes em contextos familiares como verdade, que se atualizam juntamente com a memória. Pois, como afirma a antropóloga visual Clarice Peixoto, as fotografias que participam do nosso cotidiano e que nos tocam afetivamente, "as imagens penduradas nas paredes ou sobre um móvel da sala de visitas", "constituem o tesouro familiar, a herança das gerações mais jovens". São incorporadas à memória da vida e passam a servir como referenciais espaciais, temporais e identitários, assim como "os comentários, as histórias, as lembranças evocadas por estas imagens apresentam aos jovens uma história que não viveram, mas da qual fazem parte" (Peixoto 2001: 174).

A autora chama atenção para a mesma característica de aderência memorial de imagens vinculadas a eventos históricos que remetem à memória coletiva, como as transmitidas por alguns filmes: "através das imagens de arquivo incrustadas nestes filmes, olhamos o lugar e as cenas do acontecimento com a forte sensação/emoção de que dele fizemos parte e (re)vivemos esse momento através da experiência dos seus verdadeiros atores" (Peixoto idem).

Isso não significa que os fatos não estejam pautados na verdade e que a fotografia não seja o estopim para uma imersão nesse passado memorial, mas o que não se pode desconsiderar é o caráter mitológico da fotografia, que nos auxilia a narrar a própria vida, ao mesmo tempo em que homogeneíza (conforma, produz) um discurso sobre o passado. Nesse sentido, Koury se distancia da comparação da fotografia com o "Sudário de Thurin" de Barthes (2010), uma vez que Koury propõe uma leitura menos fenomenológica sobre a fotografia, ou seja, o registro fotográfico não carrega consigo o referente, mas o representa.

Com relação à potência de arquivo que é inerente à fotografia, Koury (1996: 5) fala desta como "posse simbólica do real a partir do imaginário fixado", um desejo de domínio sobre o referente que permite catalogar, fixar, arquivar e tornar disponível, acessível. No caso particular dos acervos criados em antigas colônias para o isolamento de pessoas com lepra, mais que um desejo de catalogação, percebe-se um desejo de permanência que torna o passado acessível através do discurso conduzido pelo acervo exposto.

Esses acervos possuem ainda um compromisso moral de lembrar o tipo de tratamento dado, na primeira metade do século XX, às pessoas que foram diagnosticadas com hanseníase. Tratamento este centrado em uma política de isolamento que gerou estigma em torno dos familiares que permaneceram em suas cidades de origem, 
separou de seus pais os filhos nascidos no isolamento e nem sempre tratou bem dessas crianças, e que hoje, comumente, é justificado pelo desconhecimento dos mecanismos da doença ou pela falta de medicamentos eficazes na época. Com relação aos filhos separados, trata-se das crianças que nasceram em hospitais-colônia e foram separadas dos pais logo após o nascimento para evitar a transmissão vertical da doença de mãe para filho, o que nunca foi verificado. Essas crianças eram levadas para viver em educandários sob os cuidados das irmãs de caridade, até possuírem idade para serem adotadas.

Os mecanismos de saúde pública exerceram, portanto, um poder tutelar sobre o direito de ir e vir da população, estabelecendo novas condutas aplicadas de modo restrito aos grupos de portadores de hanseníase. Essa forma de "administração da vida que se converteu em objeto da política" (Das; Poole 2008: 32), que também foi abordada por Foucault e Agambem como "biopolítica", ou política exercida sobre os corpos, é também, segundo Veena Das, uma "política das massas corporais".

Nesse sentido, a criação de margens que separam grupos e indivíduos, com a criação de espaços de segregação como "instituições de caridade e estatais para outras enfermidades, como campos sanitários massivos", determina não apenas fronteiras sociais e subjetivas, mas novas formas de vida e de relação com o tempo. Parece que os projetos de futuro durante a reclusão limitam-se ao cotidiano, à superação diária, à luta contra a doença e às expectativas de liberdade como bem maior.

Com o fim das internações compulsórias e a abertura dos portões, entra-se num outro momento no qual é necessário lidar com o sofrimento e os traumas gerados durante o isolamento. Nesse sentido, a própria ruptura com o tecido social de origem pode ser entendida como uma forma de trauma. A ressignificação da vida e a invenção de novos tecidos tramados pelas relações humanas, em situações limitadas, são resultado da vida em ação, com o trabalho do tempo. No período posterior, o da liberdade, inicia-se um processo de superação do próprio silêncio, e novas expectativas de futuro são geradas.

É nesse sentido que se tem observado a configuração de uma militância pela consolidação da memória do grupo e pelo reconhecimento de direitos. Nessa tessitura sincrônica da vida que acessa diferentes temporalidades, a memória está sempre em processo, assim como a própria identidade individual. Pois, como disse Paul Ricouer, "A memória das 'coisas' e a memória de mim mesmo coincidem" (Ricouer 2007: 110). Com isso, as narrativas individuais sobre os eventos do passado reforçam as narrativas do grupo, ou seja, "a biografia individual se converte em texto social" (Das 2008: 87), uma vez que a comunidade se converte em veículo através do qual a experiência individual de ter sofrido alguma violação pode ser vista como experiência de toda a comunidade". Assim, são essas formas de "solidariedade ativas ou passivas" (Idem: 88), nas quais o Movimento de Reintegração das pessoas acometidas pela Hanseníase (Morhan 2010) se insere, que podemos chamar de militância.

A Colônia Santa Izabel, campo de pesquisa evidenciado neste trabalho é um dos principais centros da luta organizada pelos direitos das pessoas atingidas pela hanseníase no Brasil. Entende-se que a militância por reconhecimento, que denuncia os abusos sofridos e advoga uma indenização pela violação de direitos, é não apenas uma estratégia de ratificação do passado vivido, mas um tipo de exorcismo coletivo. Pois essa incorporação 
de direitos, ao legitimar o sofrimento individual, fortalece os indivíduos, que se identificando como um grupo que sofreu com a mesma política de estado violenta, também veem na militância a possibilidade de criação de uma nova imagem comum e de um novo futuro para si.

Para Veena Das (2008), a dor do trauma deve ser entendida dentro de uma comunidade moral, pois sentir a dor do outro é mais que um processo intelectual, é uma experiência que passa pelo corpo. Para a autora, quando alguém fala sobre a própria dor está manifestando o desejo de compartilhar. Pensando numa comunidade moral que se contrapõe à sociedade dos indivíduos, vistos como ilhas, Veena Das diz: “inclusive quando a dor se inflige com crueldade e sem nenhuma razão aparente, essa dor que destrói minha proximidade com o meu próprio corpo não pode ser tratada como uma experiência estritamente pessoal" (idem: 431). Assim, para tentar compreender os eventos traumáticos do passado e seus reflexos no presente, é necessário consolidar-se com a dor do outro, e isso requer uma incorporação do vivido. Enquanto comunidade moral, é necessário identificar a dor do outro no próprio corpo social.

Para identificar a resposta do Estado às reivindicações da militância atual, parece fortuito partir do diálogo precário estabelecido entre os Ministérios da Saúde e da Cultura em torno do reconhecimento dos antigos hospitais-colônia como lugares de memória - que são também lugares de sofrimento - que preservam "restos" (Debary 2015) do vivido no passado, e que continuam, no presente, como lugares da vida, num formato de liberdade. Lugares excepcionais devido à complexidade que encerram, não apenas pelo modus vivendi particular e homogêneo do que foi, mas também pela convivência do presente ressignificado com as memórias dolorosas do passado. Antes de tudo, o desejo de reconhecimento patrimonial desses lugares expressa uma necessidade de não pactuar com a invisibilidade programada de um erro que é significativo na história das políticas de saúde pública.

Sobre isso, em 2007, o Congresso Nacional, ao discutir o projeto de conversão da Medida Provisória 373 em lei, reconheceu como errônea a política sanitária baseada no isolamento compulsório. A política sanitária de segregação e internação compulsória executada pelo Estado brasileiro foi reconhecida como erro por violar os direitos fundamentais do cidadão hanseniano, gerando danos psicossociais permanentes (Morhan 2012). Nesse sentido, embora quase inexistente, é indiscutível a necessidade de se pensar formas de preservação das memórias individuais e coletivas para além da memória da saúde.

Seligmann-Silva (2006: 212), ao tratar da representação de memórias dolorosas no presente, fala de um dever ditado não apenas por uma necessidade pessoal, como também de ordem moral, tal como proposto por Paul Ricouer: “o dever de memória se inscreve numa problemática moral” (Ricouer 2007:104). Mas é o corpo, enquanto meio de contato, em relação ao tempo e ao espaço, o lugar por excelência em que se inscrevem as memórias: “Nesse aspecto, a simetria entre espacialidade e temporalidade é completa: 'aqui' e 'agora' ocupam o mesmo lugar, ao lado do 'eu', 'tu', 'ele' e 'ela'[...]" (idem: 59). Assim, é por meio do corpo que experimentamos e fixamos nossas lembranças; é mediado pelas emoções que o sistema límbico determina o que se retém e o que se esquece, e, ainda, é por meio de imagens mentais que as lembranças são reapresentadas, ou seja, a memória 
passa, necessariamente, pelo corpo e por "uma consciência íntima do tempo" (idem: 61). Nesse sentido, há que se considerar que as memórias traumáticas, muitas vezes recalcadas ou "subterrâneas", conforme proposto por Pollak, são produto de "um trabalho psicológico do indivíduo que tende a controlar as feridas, as tensões e contradições entre a imagem oficial do passado e suas lembranças pessoais" (Pollak 1989:10).

Muitas memórias são perpassadas por uma legião de "indizíveis", pois, por mais que se construa uma narrativa e que esta seja transmitida, é comum que, ao final da narrativa, o ouvinte se pergunte: “Mas, por quê? Qual o sentido disso?". A desumanização patente nos fatos que emergem do passado é chocante porque nos fala da nossa própria humanidade e de seus despropósitos, e, por consequência, nos fala da impossibilidade de narrar certos fatos. Impossibilidade que diz respeito à linguagem, seja ela oral, escrita ou visual. Porque há experiências que não podem ser sequer imaginadas. Fogem do plano da realidade, assumem o estatuto de um pesadelo, e é nesse sentido que o indizível pode, facilmente, ser ficcionado pelo senso comum. Mas as imagens, quando sobrevivem, mantêm vivas as memórias.

A experiência possível diante de um acervo composto por imagens e objetos é sempre intermediada por uma "estetização política da memória" (Bezerra; Serres 2015), um convite ao mergulho em uma realidade condutora de discursos a partir de uma "memória educada" (Candau 2011: 118). O desafio talvez seja encontrar a justa medida entre memória e história, para ter claro, diante do que é exposto, a "différence entre une mémoire apaisée et une mémoire falsifiée"2 (Debary 2015 :5). O ideal seria que os lugares de memória não apenas preservassem a memória e transmitissem o compromisso ético-moral de reconhecimento da dor do outro, mas que possibilitassem a incorporação dos direitos violados que se propõem destacar.

Ao tentar entender quais os valores que norteiam os processos de reconhecimento desses lugares, percebe-se, sumariamente, uma tentativa de registro do que foi a partir daquilo que sobreviveu, de seus restos materiais, vestígios no sentido indicial do termo. As memórias das pessoas que viveram essas políticas, embora sejam expostas a partir da cultura material, nem sempre estão traduzidas para o olhar do "leitor" comum, que desconhece os eventos traumáticos implicados nas políticas de isolamento. Em realidade, existem vários pontos de vista e algumas intenções de verdade. Nos meandros da qualificação desses lugares como lugares de memória, ocorrem disputas não ditas na escritura daquilo que deve ganhar evidência, o fio condutor do discurso por trás do reconhecimento: de um lado a memória oficial (condutora do saber médico e do campo da saúde), de outro a memória dos grupos (geralmente integrados à vertente dos Direitos Humanos) e, por muito tempo, silenciada. Eis "la question politiche et éthique d'une définition du juste souvenir et d'une juste mémoire: comment une société traite-elle de son passé?"3 (idem).

Para tentar entender o fenômeno da criação de memoriais como dispositivos de preservação e transmissão da memória nesses lugares de memória (hospitais-colônia), apoiamo-nos na relação orgânica que as pessoas estabelecem com a cultura material a partir de Daniel Miller, para quem os objetos aprofundam o conhecimento sobre o humano. Para isso é necessário cessarmos com a oposição entre cultura material e humanidade, como se as pessoas e os objetos não fossem feitos da mesma matéria, que aqui podemos chamar de desejo recíproco, 
pois para o autor é possível pensar que os objetos "nascem" com o desejo de serem adquiridos, de participarem de um circuito, de terem uma "vida", assim como as pessoas desenvolvem desejos sobre objetos determinados.

Assim, ao invés de pensar que os objetos "de algum modo drenam a nossa humanidade" (Miller 2013:11) - se não nos distinguirmos deles - é possível pensar que somos, com eles, uma continuidade impregnada de memória sensorial, estratos de tempo. Nessa perspectiva, os objetos "falam" de nós mais do que poderíamos falar se estivéssemos centrados apenas em sua materialidade ou em sua funcionalidade. Eles materializam desejos e memórias, são "sociotransmissores" que "favorecem as conexões" entre os indivíduos, como afirma Joël Candau (2009: 49), e podem ser "objetos biográficos", como diz Ecléa Bosi (2009:441), "quando envelhecem com seu possuidor e se incorporam à sua vida".

Assim, se considerarmos os objetos "segundo sua capacidade de objetificar valores pessoais e sociais" (Miller 2002: 165), ou ainda se pensarmos que os memoriais são formas de objetificar valores e eventos e que “em sua devoção a esses objetos, as pessoas objetificam seus ideais de identidade estável no sentido de que os objetos passam a materializar a identidade social" (idem: 143), é fácil compreender o valor que esses memoriais assumem, enquanto dispositivos de fixação e transmissão das memórias dos grupos. Nesse sentido, os eventos do passado que se quer transmitir passam a ser objetificados, gerando imagens mentais ou objetuais que podem ser entendidas como manifestações da memória.

É claro que a experiência de cada visitante diante de cada acervo nos referidos memoriais não será uniforme. Não apenas porque cada pessoa se relaciona de maneira diferente com tal experiência - alguns são trabalhadores do campo da saúde; outros são ex-pacientes ou filhos separados; outros são pessoas engajadas com movimentos políticos de reparação de direitos - mas também porque a experiência de interpretação do discurso subjetivo daquilo que é apresentado como um recordatório é individual e está sujeita aos pontos de vista de quem se coloca em contato.

Além disso, é possível afirmar que objetos, vídeos e fotografias atuem da mesma forma sobre os visitantes, visto que possuem naturezas distintas? Acredita-se que existam camadas complexas de significados entre 0 processo de emissão e recepção das mensagens. O acervo de um memorial pode ser compreendido como um conjunto de "emissores ausentes", tal como acenado pela historiadora Maine Lopes (2012) em seu estudo sobre a construção e a representação da história no Museo Nacional de la Inmigración, na Argentina. Isto porque a mensagem que chega ao presente é emanação de uma ausência, e só por isso ocupa esse lugar, com a função de lembrar algo que não mais está (Nora 1993). Contudo, é apenas no contato com o receptor que a mensagem se efetiva. Sendo assim, não existe um único sentido para a mensagem, embora existam direcionamentos, pois a linguagem, seja ela falada, escrita ou visual, está sempre sujeita a interpretação.

A linguagem utilizada como instrumento de preservação da memória em situações extremas torna-se eficaz quando os códigos são horizontalizados e acessíveis ao público. Com isso, não nos cabe avaliar os critérios museológicos utilizados para a configuração do espaço, marcado pelo sofrimento, em lugar de memória (Nora 
idem) - pois isso, necessariamente, passa por uma instrumentalização da memória, uma configuração no tempo e no espaço, como condutora de um discurso -, mas sim o estopim para a criação desse dispositivo memorial, essa vontade de memória, registro, compartilhamento. Nesse sentido, considera-se uma comunicação efetiva quando, mesmo a partir de uma apresentação caótica e fluida, os elementos do acervo e do discurso institucional se articulam, gerando caminhos para a potencial condução de significados plurivocais e o alargamento da memória coletiva.

Utilizaremos como exemplo o Memorial José Avelino, criado na antiga Colônia Santa Izabel. Trata-se de um espaço de memória criado a partir da reunião de objetos de antigos moradores e funcionários, feito por iniciativa de Helio Dutra, nascido na Colônia, com o auxílio de Maria Francisca Queiroz, que chegou à instituição com nove anos de idade. Segundo o Sr. Aldecir Pereira dos Santos, guia do Memorial José Avelino ${ }^{4}$, um dos guardiões de memória do lugar, o livro de visitantes, recebeu quatro mil pessoas até fevereiro de 2016. Esse Memorial foi criado "há uns dez anos, está sempre aberto" e recebe mais grupos de fora, "alunos, pessoas que estão fazendo estudos, pesquisas..." (Dos Santos 2016). O espaço, criado na antiga Caixa Beneficente, ao lado do Cineteatro Glória, localizado na chamada "zona suja" da colônia, dispõe de objetos que permitem visualizar alguns aspectos da vida coletiva do lugar. Tanto no que diz respeito aos instrumentos da área da saúde - que ilustram alguns dos tratamentos disponíveis na época e formas de manifestação da doença já superadas - como no que se refere às atividades comunitárias desenvolvidas no interior da colônia durante o tempo em que a internação era compulsória.

Dentre esses objetos, seria possível elencar brevemente: fantasias do antigo bloco de carnaval Unidos de Citrolândia, criado pelo morador e carnavalesco Geraldo Silva, vulgo Capacete, juntamente com outro exmorador já falecido; utensílios domésticos; ferramentas de manutenção do espaço público; instrumentos de uso agrário; troféus dos antigos campeonatos onde o Minas Esporte Clube foi campeão; instrumentos musicais da antiga banda de jazz; ampliações de fotografias de eventos realizados no local; recortes de jornal; instrumentos médicos e de dissecação; triciclos adaptados para manipulação com as mãos; aparelhos de som de diversos períodos; telefones; moldes para próteses; projetores de cinema, entre outros.

O historiador Pierre Nora chamou atenção para o aspecto residual da memória dos lugares quando cunhou a expressão "lugares de memória". Para o autor "a memória se enraiza no concreto, no espaço, no gesto, na imagem, no objeto" (Nora 1993: 9). Nessa definição, Nora deixa claro que os lugares de memória não são necessariamente materiais, mas estão, acima de tudo, vinculados às experiências humanas. A característica imaterial dos suportes de memória possibilita uma interpretação dos lugares de memória como lugares que já foram ocupados, demarcados pelo afeto, e reativados pela rememoração, pela evocação do que está ausente. Nesse sentido, os lugares fornecem algo que a história, enquanto ciência de caráter universal, não poderia alcançar, uma dimensão sensível e afetiva que se mantém viva a partir da memória. 
Apesar de falarmos em "lugar de sofrimento" e "memórias dolorosas", no interior do Memorial não se identifica um discurso da dor. Ao invés disso, percebem-se os resquícios de um modo de vida peculiar, registros do passado "em comum", entre grupos de pessoas que durante um período de suas vidas foram tratadas como "exilados sanitários", um passado marcado por cortes e rupturas emocionais, que ainda resiste às ações do tempo tendo como suporte o desejo de memória e alguns registros, sobreviventes, do passado. Mas, “Como mostrar as violências extremas?" (Debary 2015; Becker 2013). Além de ética, a questão é necessária para fomentar uma reflexão mais cuidadosa com relação a essa corrente de reconhecimento sobre o sofrimento no tempo presente e às diversas apropriações e narrativas geradas em nome de memórias silenciadas no âmbito comum. Na imagem, abaixo, apresentamos um ângulo do Memorial José Avelino.

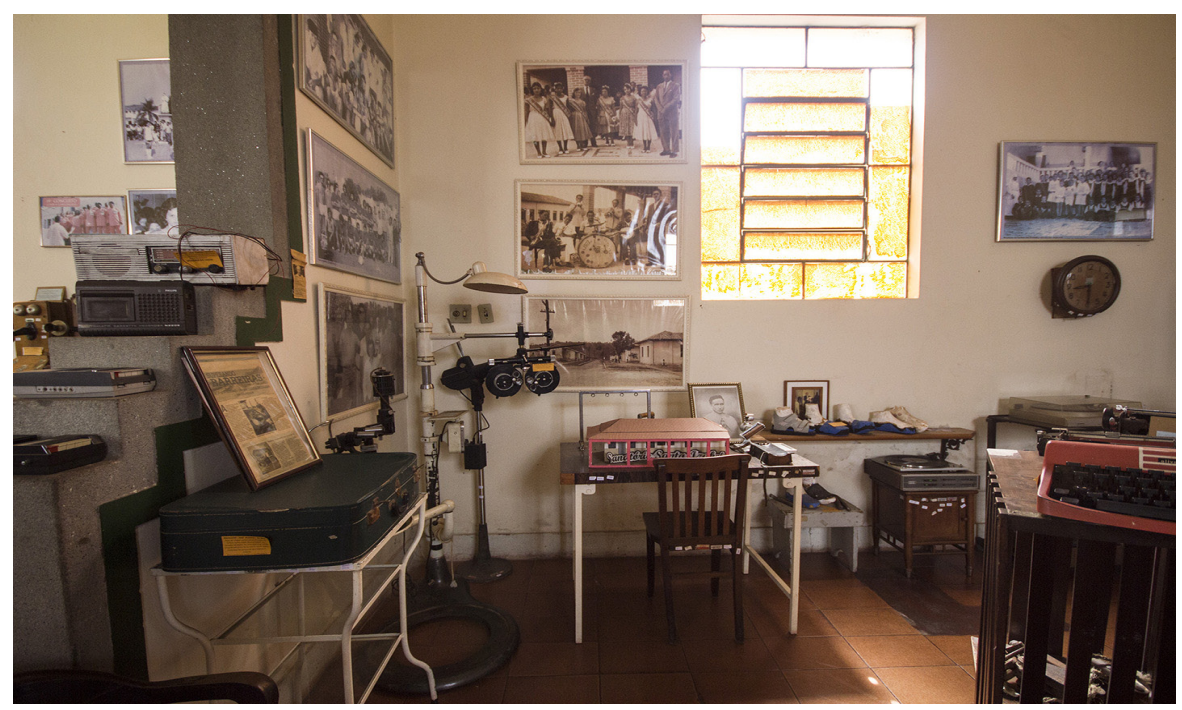

Figura 1: Ângulo do Memorial José Avelino, Colônia Santa Izabel. MG, 2016. Fotografia: Daniele Borges

Ao imergir nesse universo, têm-se a sensação de adentrar um relicário, um local destinado à preservação da memória frágil de um modo de vida que já não mais existe, que se configura como um lugar de memória, ou seja, como "suportes exteriores e de referências tangíveis de uma existência que só vive através delas" (Nora 1993: 14). Todo o complexo da antiga colônia exibe vestígios do passado, que podem ser escavados por um olhar atento dentre as ruínas que contrastam com o estilo caótico, gerado pelo crescimento urbano e pelas apropriações indevidas do espaço. Contudo, entrar no memorial deflagra uma forma de empatia com as 
memórias do passado que não ocorre no passeio público. Percebe-se o memorial como expressão de um desejo de memória. A criação deste espaço que se propõe a guardar e expor de modo muito intuitivo e que enfrenta problemas de ordem estrutural - tais como: umidade, infiltração, formas inadequadas de armazenamento e exposição - exprime um desejo de transmissão, contrário à ocultação proposta pela política de isolamento que deu origem aos hospitais-colônia.

Talvez de modo inconsciente, esta seja uma forma de validar as narrativas sobre o passado, narrativas sobre memórias indeléveis no âmbito íntimo, mas pouco conhecidas para além das fronteiras geográficas das antigas colônias. Seriam os memoriais e seus acervos, compostos de objetos e imagens, instrumentos de preservação da memória que permitem que experiências indizíveis sejam imaginadas? Nesse sentido, em que medida participam as imagens? Em que medida fenômeno, memória, arquivo e desejo estão imbricados? Para o antropólogo Etienne Samain:

[...] não olhamos da mesma maneira uma fotografia ou as imagens que um filme desenrola. Nossas posturas são fenomenologicamente diversas. São atos de observação, posturas de olhar, distintas. 'Assiste-se' um filme, 'mergulha-se' numa fotografia. Enquanto as imagens projetadas levam o espectador num fluxo temporal contínuo, que procura seguir e entender, as fotografias, por sua vez, o fixam num congelamento do tempo do mundo e o convidam a entrar na espessura de uma memória. (2012b: 159).

Do ponto de vista de Samain (idem), as imagens podem ser consideradas arquivos de memórias, as memórias são fixadas na forma de imagens e as imagens são fenômenos que atuam atreladas aos desejos. Sem pretender simplificar o que foi dito pelo autor, chama-se atenção para a complexidade do processo memorial intimamente ligado à imagem. Se considerarmos a imaginação como mise en scène de fragmentos da memória em imagens mentais, torna-se evidente que imagem e oralidade são partes constituintes do ser, da comunicação e de nossa relação com o mundo. De modo que a imaginação se impõe anacrônica, a despeito da obsessão humana em situar-se de modo cronológico. Talvez mais importante que situar no tempo seja a capacidade de visualizar no tempo.

Nesse sentido, a visitação e o contato com os acervos de memoriais que narram experiências extremas, compostos por objetos, audiovisuais e imagens, geram uma imagem para a memória que é localizada de modo muito mais emocional e subjetivo do que histórico, pois apesar de narrar uma história ou permitir que o visitante se situe no tempo que estes objetos evocam, eles são mais que documentos históricos, atuam sobre os sentidos e as sensibilidades no presente, assim como a fotografia expandiu-se de sua potência inicial de autenticar uma situação e também está aberta a interpretações. A única coisa que é possível afirmar é que "isso foi", tal como elaborado por Roland Barthes (2010: 89). É claro que cada um pode sair do memorial com uma interpretação acerca dos fatos, e a construção epistemológica de cada um será pessoal. Mas o que isso foi é impossível de ser compreendido apenas pela exposição dos objetos, pela leitura das fotografias, e até mesmo pela narrativa oral das pessoas que viveram esse passado marcado por eventos dolorosos.

Os estudos com imagens relativos a eventos traumáticos (Seligmann-Silva 2006; Didi-Huberman 2003; Sontag 2003), tais como o emblemático Auschwitz, têm demonstrado a necessidade de se "pensar a 
incomensurabilidade entre a representação e o evento" (Seligmann-Silva 2006: 212-213), a impossibilidade de representação. Nesse sentido, este espaço de silêncio povoado pelo indizível e marcado por ausências de toda ordem também é emblemático e pode funcionar como um monumento à memória. Quiçá um antimonumento, tal como o obelisco do artista Jochen Gerz, "Monumento contra o fascismo", que convida os transeuntes primeiro a um registro da passagem gradual do tempo, com a retração silenciosa do obelisco ao subsolo, e simboliza a perda, a invisibilidade, e depois obriga os transeuntes a conviver com o vazio repleto de significados que emanam desse sepultamento.

Ainda a propósito do registro no domínio da ausência e do vazio, a imagem abaixo (figura 2) ilustra a história de um abraço que nunca foi dado. A pessoa que segura a foto, Maria das Dores, à direita, narra com muita emoção que sua mãe, ao centro da foto, fugiu do pavilhão feminino e foi até o Educandário Pindorama, onde Maria e a irmã, à esquerda, viviam desde a separação, no nascimento, para fazer uma foto com as filhas. Quando foram descobertas, ambas foram castigadas e nunca mais se viram. Essa imagem ocupa hoje o espaço do vazio da convivência, ao mesmo tempo em que simboliza o afeto da mãe pelas filhas, o desejo de um abraço que nunca foi dado, pois se observarem na foto as mãos de ambas estão atrás do corpo, e reforçam o interdito do toque. Com essa fotografia, a mãe de Maria das Dores registrou a impossibilidade do abraço. Abraçou-a pelos olhos?

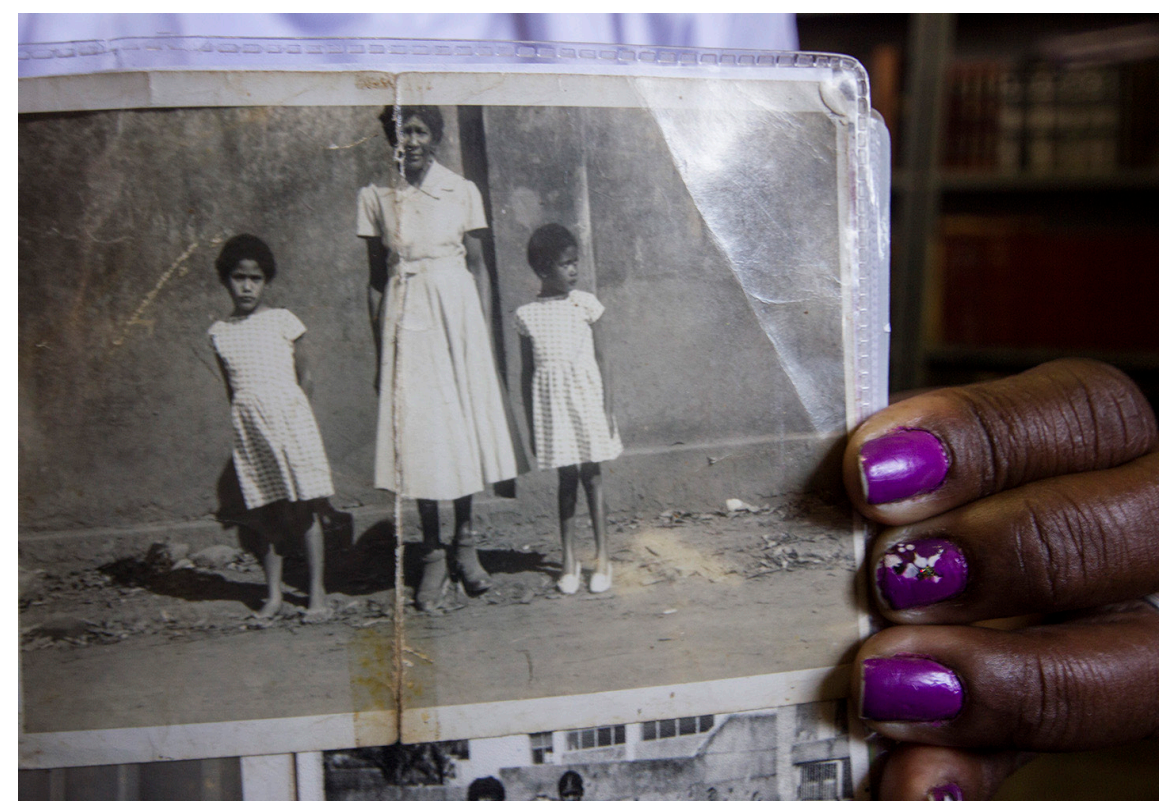

Figura 2: A única foto que Maria das Dores possui de sua mãe. Memorial José Avelino, Colônia Santa Izabel. MG, 2016. 
A mesma posição corporal registrada na fotografia de família de Maria das Dores, com as mãos para trás, pode ser percebida na forma como Maria Emerenciano, hoje com 60 anos, filha separada ao nascer, se apresenta para o retrato no presente. Hoje ela superou as experiências do passado, se reconstruiu, mas as memórias seguem vivas, sobretudo com relação à experiência traumática envolvendo tentativa de abuso sexual por parte de um interno, dentro da colônia: “eu fiquei com isso na cabeça. Eu sofri muito" (Emerenciano 2016). A imagem que segue é exemplar da introjeção de "técnicas corporais", proposta por Marcel Mauss (2003), neste caso, uma postura corporal imposta pelo modo de vida no Educandário.

A compreensão da postura corporal visualizada anos depois em alguém que viveu a mesma experiência, através do tempo, torna-se perceptível a partir da potência da imagem enquanto método científico, pois a imagem

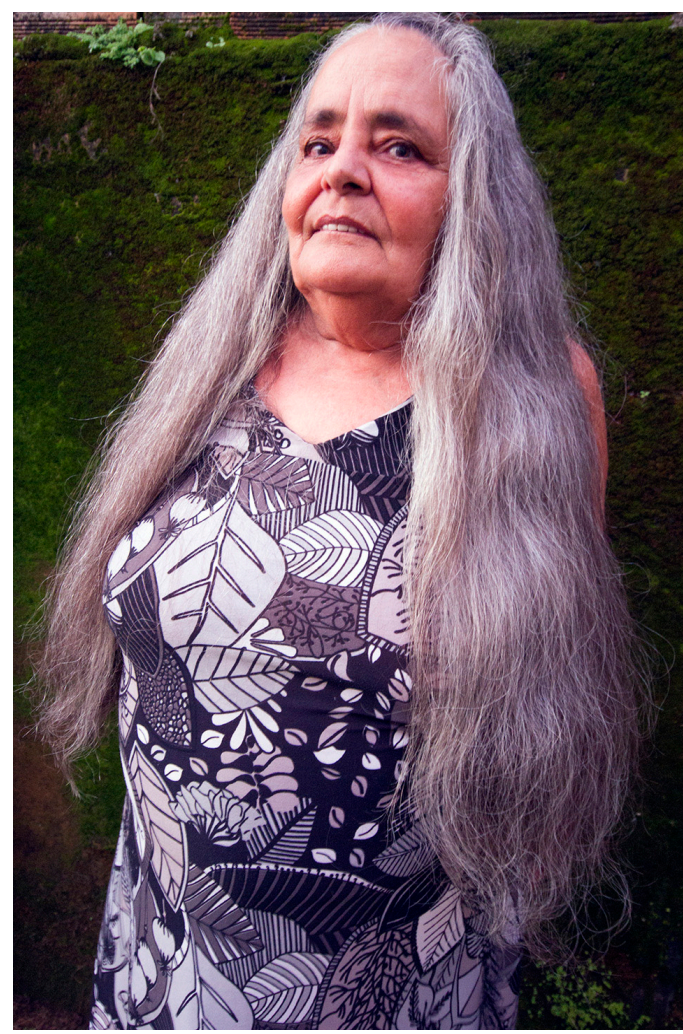

Figura 3: Retrato de Maria Emerenciano Colônia Santa Izabel. MG, 2016

Fotografia: Daniele Borges resulta não apenas de uma necessidade de aproximação com o campo, ou de registro para a memória, mas também como um instrumento que permite identificar elementos e elaborar nexos que não pudemos ver durante a imersão no campo, ou que precisaram de tempo para se tornarem claros, após muitos encontros reflexivos com a mesma imagem, e ainda, que só foram compreendidos porque houve comunicação entre as imagens, e porque elas provocaram indagações ( $\mathrm{Cf}$. Samain 1995).

As imagens são arquivos, afirma Samain, parafraseando Derrida (2001) em Mal de arquivo, e os arquivos

não são apenas lugares de lembranças redescobertas que precisariam de reanimações. Devem ser encarados como sendo presente, inquietações e questões para pensar, interrogar, levantar nosso presente [...] (Samain 2012b:161).

De modo preliminar, é possível propor duas questões. É possível identificar um discurso que sustente o acervo desse espaço de memória? Em que medida as pessoas se veem refletidas nesse espaço de memória? A primeira questão pode rapidamente ser respondida, uma vez que se considere o desejo de memória como alicerce do memorial. Uma vez que isso esteja claro, os discursos são construídos e apropriados, de modo subjetivo, por cada visitante.

Contudo, ao olhar desavisado de um visitante, a mesa de dissecação pode parecer um simples suporte para outros objetos postos em evidência. Percebe-se que a escolha dos 


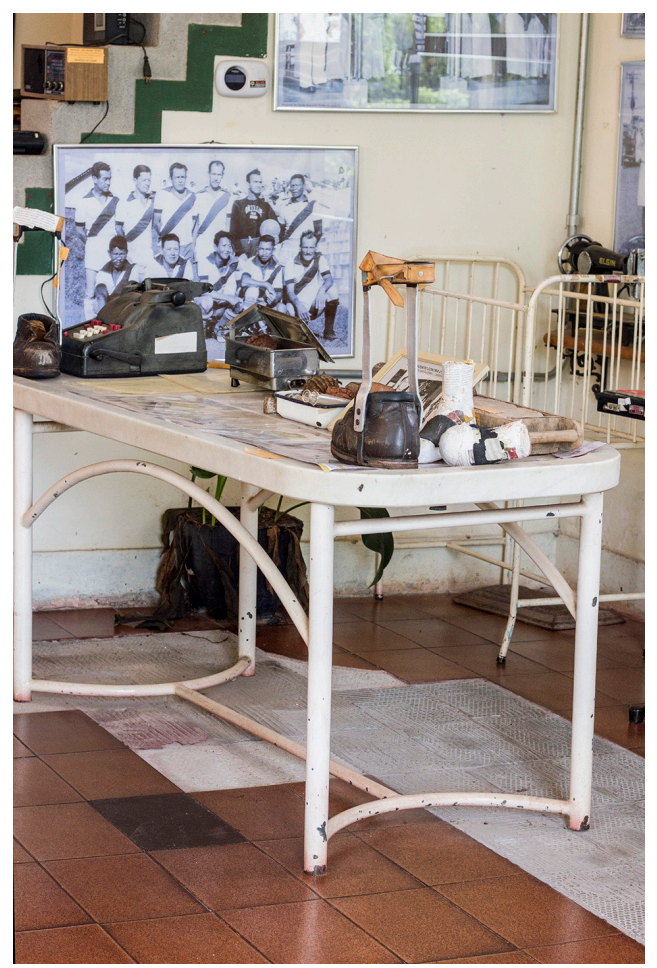

Figura 4: Mesa de dissecação com tampo de mármore e outros objetos. Memorial José Avelino, Colônia Santa Izabel. MG, 2016.

Fotografia: Daniele Borges objetos que são evidenciados e dos que funcionam como suporte não segue uma lógica expográfica projetada por um profissional do ramo da museologia. Simplesmente demonstram uma forma de acomodar os restos, de "montrer ce qui n'est plus à partir de ce qui reste, um reste irréductible que l'on conserve [...]"5 (Debary 2015:7), numa tentativa de preservar a memória de um lugar constituído de contrastes, de um passado marcado pelo sofrimento e da fluidez da vida encontrando novos caminhos e novos significados.

O imperativo da preservação caminha de braços dados com o sentido conciliatório que, de modo geral, trouxe alguma paz ao presente. O desejo de memória parece ser um dever moral individual com a sua própria identidade, pois, embora não rememorem o passado constantemente no presente, os moradores da antiga colônia carregam consigo experiências dolorosas que estão incrustadas na história de vida de cada um, pois "lembrar-se de algo é lembrar-se de si" (Ricouer 2007:136). Nesse sentido, a lembrança aparece como "uma espécie de imagem e a recordação como uma empreitada de busca" (idem: 135).

Assim, o encontro com a mesa de dissecação, mencionada acima, pode ser vivenciado num espaço evocativo de apelo profundamente emocional, servir como instrumento de pesquisa no campo da história da saúde e, ainda, exercer o mesmo efeito que um gabinete de curiosidades, isso não depende apenas de "o que" são ou de "como" estão dispostos os elementos que

integram o memorial, tampouco depende de qual versão da memória está sendo narrada. Depende também de quem visita o lugar e do que consegue ver/identificar/ler na espessura subjetiva, sutil, que torna únicos os elementos que compõem o acervo. O reconhecimento e a salvaguarda de lugares de sofrimento, bem como a criação de memoriais que narram a história das vítimas, têm sido tangenciados pela ideia de um "dever de memória" relacionado à violação de direitos, um "imperativo de justiça" inscrito "numa problemática moral" (Ricouer 2007: 104).

Arriscamo-nos a propor que uma experiência capaz de transmutar a percepção sobre os restos históricos (de experiências indizíveis) em ícones de um erro político que não pode tornar a acontecer, apenas seja possível a 


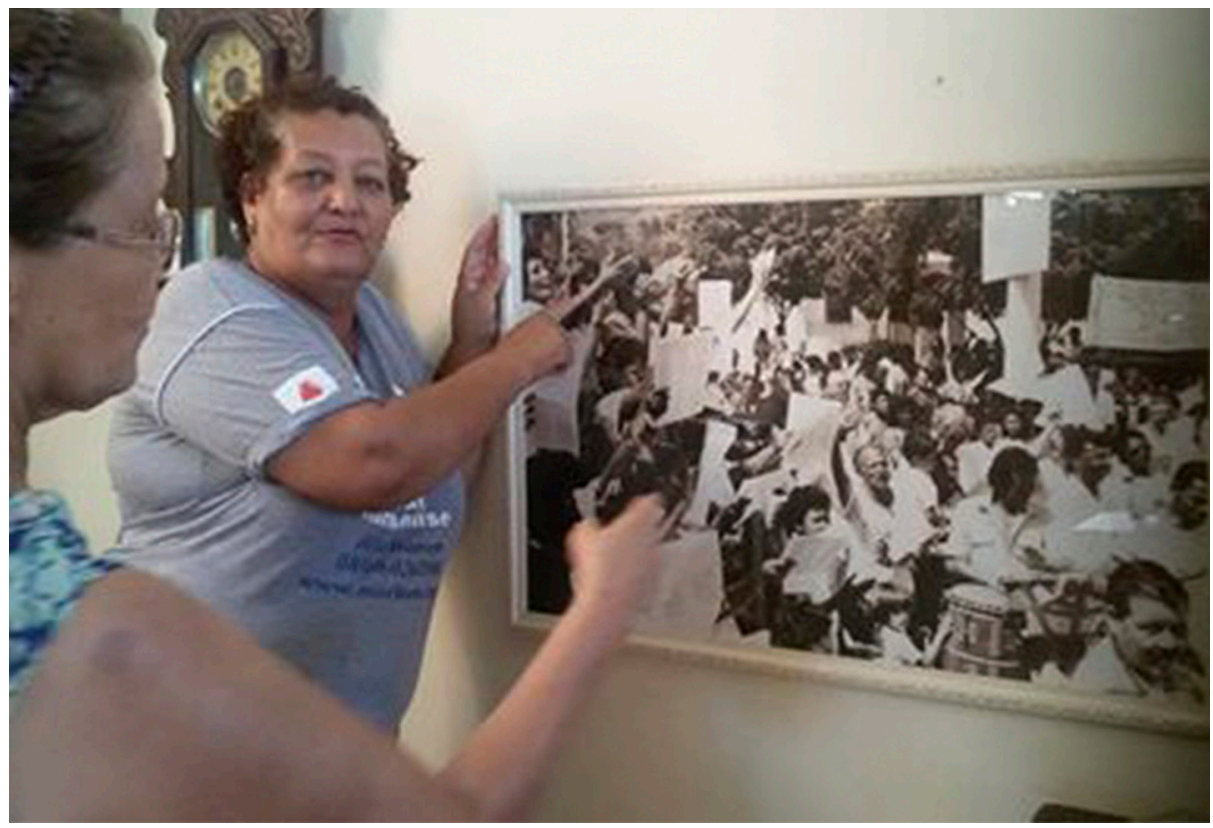

Figura 5: Eva Nascimento se identifica na fotografia e fala sobre a despedida de alguém importante na Colônia. Memorial José Avelino, Colônia Santa Izabel. MG, 2016.

Fotografia Daniele Borges

partir de uma experiência de caráter ético-moral, situada entre empatia e imaginação, que conecte o testemunho em primeira pessoa, possibilitado pela história oral, e a "pensatividade" (Samain 2012) das imagens.

Com relação à segunda questão: “Em que medida as pessoas se veem refletidas nesse espaço de memória?", ficou evidente, após a imersão no campo por uma semana, que na antiga Colônia Santa Izabel, cujo memorial foi erigido com a participação efetiva da comunidade - embora as visitas pelos antigos moradores não sejam muito frequentes, por se tratar de um lugar que já lhes é familiar -, entrar no memorial é como abrir um álbum de fotos de família, onde todos se reconhecem e imediatamente começam a descrever as paisagens da memória que cada elemento Ihes evoca.

Imagem emblemática que colabora para esta afirmação é a fotografia da antiga moradora Eva Nascimento (Figura 5), na qual se pode perceber que a identificação com a imagem do passado exposta no memorial foi 
instantânea, e a narrativa sobre o passado, espontânea. Embora de naturezas distintas, objetos e fotografias partilham de uma mesma qualidade evocativa onde a memória se demora, podendo ser considerados, mais do que simples suportes passivos de memória, como lugares de memória, lugares onde a "memória trabalha" (Nora 1993), memória viva de algo extinto. Spinoza, para quem os afetos assumem a forma de afecções sobre o corpo, propõe que "o homem é afetado pela imagem de uma coisa pretérita ou futura com o mesmo afeto de alegria ou tristeza que pela imagem de uma coisa presente" (Spinoza 1987:191), o que equivale a dizer que a afetação por imagens do passado é sincrônica.

É como se os vestígios do passado falassem, e ao falar preenchessem os espaços vazios do presente com os fantasmas daqueles que viveram no lugar. Os memoriais criados em campos de concentração, por exemplo, hoje delatam um crime histórico, de modo que é impossível não lembrar o que aconteceu no lugar. Contudo, toda a memória construída a respeito desses lugares resulta das diversas narrativas do holocausto às quais tivemos acesso (Peixoto 2001). Afinal de contas, não vivemos essas memórias. Nesse sentido, os lugares de memória, tal como proposto por Pierre Nora (1993) têm essa imponente potência evocativa que pode afetar o visitante como uma ferida moral aberta. Com isso pretende-se dizer que as emoções provocadas por lugares de memória e os dispositivos que narram os eventos passados devem ser considerados sob o ponto de vista ético, moral, psicológico e estético (Seligman-Silva: 2009).

Para Didi-Huberman (2003), imagens de eventos dolorosos como as de Auschwitz envolvem muito mais a imaginação do que a identificação e estão localizadas "sur le plan de la connaissance et de la transmission"6 (idem: 113), são imagens cortantes, imagens de horror, imagens indizíveis para quem viveu. E por isso "cette phénomènologie du 'double régime' de l'image apparaît donc, tout aussi bien, comme la description d'un moment éthique du regard [...]"7 (ibidem :112) onde os registros visuais não agem como "témoin dans I'assurance subjective, mais dans un savoir à faire passer, à mettre en mouvement, à partager collectivement comme 'bien' et comme 'tourment'" (op. cit.) ${ }^{8}$.

Através das imagens é possível identificar um "olho que pensa" (Barthes 2010: 54). O olho que manipulou a câmera e registrou o momento e também o olho que tem contato com a imagem no tempo presente. Nesse sentido, as imagens não têm consciência, mas estão cheias de vida e prenhes de um imperativo ético que emana do passado em direção ao futuro, como veículo de transmissão. Contudo, é fundamental estar atento às possibilidades de "deformação na realidade do que se quer observar e descrever [...]" (Samain 1995: 45) a partir da produção de discursos, sejam eles expressos em imagens, a partir da exposição de objetos organizados num memorial, ou dos textos escritos. 
Para além da estrutura das imagens e buscando uma aproximação com a experiência imersiva em memoriais e museus, é possível propor que esses espaços de memória se apropriem de objetos e fotografias em sua potência anime, que põe em movimento, com certa vitalidade, uma série de construções mentais intermediadas por imagens mentais que passam a ocupar o vazio de eventos passados.

Para Roland Barthes a fotografia "é a imagem viva de uma coisa morta" (Barthes 2010:89), por certo esta aderência do referente ao signo, no presente, viabiliza a emanação das memórias de elementos ausentes, no presente. O que Paul Ricouer chamou de eikon, representação presente de uma coisa ausente, que "contém em si mesma o outro da afecção original" (Ricouer 2007:67). Assim, o passado, evocado por lembranças-imagens, afeta o presente. Trata-se de uma imagem mental.

Spinoza, em sua proposição XVI, nos faz pensar na vinculação subjetiva de significados a partir dos objetos, enquanto suportes materiais de memórias, e os sentimentos humanos por eles disparados quando associados a eventos passados. É como se, por meio de determinados objetos, pudéssemos imaginar o que foi, e de modo inconsciente sentir o que eles nos mostram no presente. Ou seja, associamos memórias aos objetos, que se tornam evocadores de emoções. Assim, “[...] quando a alma é afetada pela sua imagem, será também afetada, desta forma, por um ou outro afeto, e, por conseguinte a coisa em que percebemos isso [...] será causa, por acidente, de alegria ou de tristeza" (Spinoza 1987 :189-190).

Spinoza traça uma relação entre imagem e afeto quando propõe que a imagem de algo nos afete de maneira positiva ou negativa, de acordo com aquilo que evocamos a partir do contato físico ou mental com ela. $\mathrm{O}$ autor diz ainda que

[...] o simples fato de imaginar que uma coisa é semelhante em algo a um objeto que geralmente afeta a alma com alegria ou tristeza, ainda que esse em que se assemelham não seja a causa eficiente de tais afetos, amaremos ou odiaremos essa coisa (idem).

Nesse sentido, é interessante pensar na profunda afetação que é viver num lugar originalmente criado para isolar e na contraditória função memorial desses lugares e seus espaços de memória, cujo objetivo é manter viva a memória da violência que esse sistema de isolamento representa, mais do que falar do modo de vida peculiar desses lugares. Pensando a partir de Spinoza, o lugar como um todo, com seus vestígios de passado expressos na arquitetura e nos objetos da cultura material preservados como acervo do memorial, é, em algum nível, agudo em relação à memória de quem viveu e possui, ainda hoje, a potência de afetar-nos enquanto seres humanos, estranhos a essa história e, contudo, imbricados nela, pois a partir do momento que somos afetados carregamos parte dessa história conosco. 
Por fim, ousa-se propor que os dispositivos de preservação da memória, criados especificamente em lugares de memória, lidam com a produção de imagens mentais para a memória. Imagens que permitem a projeção mental de imagens. O olho pensa, e é por isso que estamos aqui, imersos em imagens. Imagens mentais que se transformam em narrativas retóricas e desdobram-se em outras imagens. Imagens de imagens que nos permitem ver para além da superfície objetiva de qualquer suporte. Eis a chance de dar luz às memórias invisíveis.

Daniele Borges Bezerra é Mestra em Memória Social e Patrimônio Cultural pela Universidade Federal de Pelotas (UFPel) e Doutoranda no Programa de Pós-Graduação em Memória Social e Patrimônio Cultural pela Universidade Federal de Pelotas (UFPel).

Juliane Conceição Primon Serres é Doutora em História pela Universidade do Vale do Rio dos Sinos. Mestra em Museologia pela Universidad de Granada (UGR/ES) e 


\section{NOTAS}

1 Refere-se ao livro, de caráter autobiográfico, que tem previsão de lançamento em julho deste ano.

2 "(...) diferença entre uma memória apaziguada e uma memória falsificada" (Debary 2015:5). Essa e todas as traduções nas notas seguintes são das autoras.

3 “(...) aqui a questão política e ética de uma definição de justa lembrança e justa memória: Como uma sociedade trata do seu passado?" (idem).

$4 \mathrm{O}$ nome do Memorial foi escolhido em homenagem ao primeiro interno do Hospital Colônia Santa Izabel, que também foi delegado da Colônia no período do isolamento.

5 "Mostrar o que não é mais a partir do que resta, um resto irredutível que foi conservado [...]" (ibidem: 7).

6 "no plano do conhecimento e de sua transmissão" (op. cit: 113).

7 "Essa fenomenologia do 'duplo regime' da imagem aparece então, também como a descrição de um momento ético do olhar (...)" (/oc. cit.: 112)

8 "(...) um testemunho seguro em nível subjetivo, mas como um saber transmitir, colocar em movimento, partilhar coletivamente como 'bem' e como 'tormento'" (cf.). 


\section{REFERÊNCIAS BIBLIOGRÁFICAS}

BARTHES, Roland. 2010. A Câmara clara: nota sobre a fotografia. Portugal: Edições 70.

BECKER, Annette; DEBARY, Octave. (Org.) 2013. "Montrer les violences extremes". Gradhiva. Disponível em: <http:// gradhiva.revues.org/2764>. Acessado em 13 de junho de 2014.

BENJAMIN, Walter. s/d. "Charles Baudelaire: Um lírico no auge do capitalismo". Obras escolhidas, vol. III. Tradução: José Carlos Martins Barbosa; Hemerson Alves Baptista. Editora brasiliense.

BEZERRA, Daniele Borges; SERRES, Juliane Conceição Primon, 2015. A estetização política dos lugares de memória. Revista história, histórias. Revista da Pós-Graduação em História da UNB. Brasília, Vol. 3, nº 6. Disponível em: <http:// periodicos.unb.br/index.php/hh/article/view/16058>. Acessado em 12 de dezembro de 2016. p. $173-187$.

BORGES, Jorge Luis. 2007. Funes, o memorioso. Tradução: Davi Arrigucci Jr. São Paulo: Companhia das letras.

BOSI, Ecléa. 2009. Memória e sociedade: Lembranças de velhos. São Paulo: Companhia das letras.

BRASIL. 1995. Lei No 9.010, de 29 de Março de 1995. Dispõe sobre a terminologia oficial relativa à hanseníase e dá outras providências. Diário Oficial da União, Seção 1, 30 Mar. 1995, p. 4509. Disponível em: <http://www2.camara.leg.br/legin/ fed/lei/1995/lei-9010-29-marco-1995-348623-publicacaooriginal-1-pl.html>. Acesso em: 6/04/2017.

CANDAU, Joël. 2009. “Bases antropológicas e expressões mundanas da busca patrimonial: memória, tradição e identidade". Memória em rede. Pelotas, v. 1, n.1, Já./ Jul. Disponível em: < http://lasmic.unice.fr/PDF/candau-article-10. pdf $>$. Acessado em 08 de junho de 2016.

2011. Memória e identidade. Tradução: Maria Leticia Ferreira. São Paulo: Contexto.

DAS, Veena. 2008. Sujetos del dolor, agentes de dignidad. (Ed.) ORTEGA, Martinez Alberto.Universidad Nacional de Colombia. Faculdad de Ciencias humanas: Pontificia Universidad Javeriana, Instituto Pensar. Disponível em> < https:// www.academia.edu/206626/Veena_Das_Sujetos_del_dolor_agentes_de_dignidad > Acessado em 02 de junho de 2016.

DAS, Veena; POOLE, Deborah. 2008. “El estado y sus márgenes. Etnografías comparadas". Revista Académica de Relaciones Internacionales, núm. 8 junio. Disponível em: < http://www.relacionesinternacionales.info/ojs/article/view/112. html> Acessado em 02 de junho de 2016.

DEBARY, Octave. 2015. “La Pierre et la peine. Représentations et historicisations de I'holocauste”. Revista Memória em Rede. Pelotas, V. 7, n.13, Jul./ dez.

DERRIDA, Jacques. 2001. Mal de arquivo: uma impressão freudiana. Tradução: Cláudia de Moraes Rego. Rio de Janeiro: Relume Dumará.

DIAS, Ana. 2016. Memórias. Colônia Santa Izabel, MG. Entrevista concedida a Daniele Borges Bezerra.

DIDI- HUBERMAN. 2003. Images malgré tout. França: Les éditions de minuit.

DOS SANTOS, Aldecir Pereira. 2016. Memorial José Avelino. Colônia Santa Izabel, MG. Entrevista concedida a Daniele Borges Bezerra..

DUBOIS, Philippe. 2012. O ato fotográfico e outros ensaios. Tradução Marina Appenzeller. Campinas: Papirus.

EMERECIANO, Maria. 2016. Memórias. Colônia Santa Izabel, MG. Entrevista concedida a Daniele Borges Bezerra. 
étnico, resistências e luta por direitos". Anais... Junho. Disponível em: < http://eventos.livera.com.br/ trabalho/98-1020312_27_06_2015_23-43-01_3443.PDF>. Acessado em 12 de junho de 2016.

FIOCRUZ. 1962. DECRETO No 968, de 7 de maio de 1962. Disponível em <http://www.fiocruz.br/historiadahanseniase/ media/Decreto968.pdf >. Acessado em 15 de fevereiro de 2016.

GOFFMAN, Erving. 2003. Manicômios, Prisões e Conventos. São Paulo: Ed. Perspectiva, $7^{\mathrm{a}}$ Ed.

HALBWACHS. Maurice. 2006. A memória coletiva. Traduzido por: Beatriz Sidou. São Paulo: Centauro.

JANELA da alma. 2001. Roteiro e direção de João Jardim e Walter Carvalho. Intérpretes: José Saramago, Hermeto Pascoal, Oliver Sacks, Wim Wenders e outros. Copacabana filmes. 1 filme (73 min), son, color. $35 \mathrm{~mm}$.

KOURY, Mauro Guilherme Pinheiro. 1996. Relações imaginárias: A fotografia e o real. XX Reunião anual da Associação Nacional de Pesquisa e Pós-Graduação em Ciências Sociais, Caxambú (MG), out. Disponível em < http://portal.anpocs. org/portal/index.php?option=com_docman\&task=doc_view\&gid=5478\&ltemid=361 >. Acessado em 08 de junho de 2016.

LOPES, Maine Barbosa. 2012. O Museo Nacional de la imigración: história, memória, representação. São Leopoldo: Oikos Editora Unisinos.

MAUSS, Marcel. 2003 Sociologia e antropologia. Tradução Paulo Neves. São Paulo: Cosac Naify.

MENEZES, Ulpiano Bezerra de. 1998. Memória e cultura material: documentos pessoais no espaço público. Revista Estudos Históricos, Rio de janeiro, v. 11 n. 21.

MILLER, Daniel. 2002. Teoria das compras. São Paulo: Nobel.

2013. Trecos, troços e coisas: Estudos antropológicos sobre cultura material. Tradução: Renato Aguiar. Rio de Janeiro: Zahar.

MOREIRA, Maria das Dores. 2016. Memórias. Colônia Santa Izabel, MG. Entrevista concedida a Daniele Borges Bezerra.

MORHAN. 2010. "Projeto Acervo". Cadernos do Morhan n.6. Disponível em: <http://www.morhan.org.br/views/upload/ caderno_06_acervo_BAIXA.pdf>. Acessado em 10 de janeiro de 2016.

2012. "Filhos separados: a segunda geração". Cadernos do Morhan n.8. Disponível em: http://www.morhan.org. br/views/upload/cadernosmorh8.pdf. Acessado em fevereiro de 2016.

NORA, Pierre. 1993. “Entre memória e história: a problemática dos lugares". Tradução Yara Aun Koury. In: Projeto história. Revista do Programa de Estudos de Pós-Graduados em História e do Departamento de História da PUC- SP. São Paulo: Educ.

PEIXOTO, Clarice Ehlers. 2001. “Memória em imagens: uma evocação do passado" In KOURY, Mauro Guilherme. Imagem e Memória. Ensaios em Antropologia Visual. RJ: Garamond.

POLLAK, Michael. 1989. "Memória, esquecimento, silêncio". Estudos Históricos, Rio de Janeiro, vol. 2, n. 3, p. 3-15. Disponível em: < http://www.uel.br/cch/cdph/arqtxt/Memoria_esquecimento_silencio.pdf.> Acessado em 12 de junho de 2014.

QUEIROZ, Maria. 2016. Memórias. Colônia Santa Izabel, MG. Entrevista concedida a Daniele Borges Bezerra.

RICOUER, Paul. 2007. A memória, a história, o esquecimento. Tradução Alain François. Campinas: Editora da Unicamp.

SAMAIN, Etienne. 1995. “'Ver' e 'Dizer' na tradição etnográfica: Bronislaw Malinowski e a fotografia." Horizontes antropológicos, Porto Alegre. (1)- Jul./ set. 
. (Org.). 2012a. "As imagens não são bolas de sinuca" In: Como pensam as imagens. Campinas: Editora da Unicamp. 164, jan-jun.

2012b .“As peles da fotografia: fenômeno, memória, arquivo, desejo". Visualidades, Goiânia. V. 10 n. 1 pág. 151-

SANTOS, Eva. 2016. Memórias. Colônia Santa Izabel, MG. Entrevista concedida a Daniele Borges Bezerra.

SÃO PAULO. 1977. Decreto $n^{\circ} 10.040$, de 25 de julho de 1977. Dispõe sobre a terminologia ofícial relativa à Hanseníase e dá providências correlatas. Diário Ofícial do Estado, Caderno do Poder Executivo, 26 Jun. 1977, p. 5. Disponível em <http://dobuscadireta.imprensaoficial.com.br/default.aspx?DataPublicacao $=19770726 \&$ Caderno $=$ Poder $\% 20$ Executivo\&NumeroPagina=5>. Acesso em 06/04/2017.

SELIGMANN-SILVA, Márcio (Org.). 2006. Palavra e imagem: memória e escritura. Chapecó: Argos.

.2009. Estética e política, memória e esquecimento: novos desafios na era do Mal de Arquivo. Remate de Males. 29 (2). Jul./dez.

SPINOZA, Baruch. 1987. Ética. Tradução Vidal Peña. Madrid: Alianza Editorial.

SONTAG, Susan. 1984. A doença como metáfora. Tradução de Márcio Ramalho. Rio de Janeiro: Edições Graal. 2003. Diante da dor dos outros. Tradução Rubens Figueiredo. São Paulo: Companhia das letras. 2004. Sobre fotografia. Tradução Rubens Figueiredo. São Paulo: Companhia das letras. 


\section{Memorial José Avelino: Um lugar de memória para iluminar memórias invisíveis}

\section{RESUMO}

Este trabalho é resultado de reflexões no campo da memória e do patrimônio, seguindo uma vertente de estudos multidisciplinares sobre processos de patrimonialização e recebe influência direta dos campos da história e da antropologia visual. Entende-se a fotografia enquanto método e objeto de estudo, mas, sobretudo, como um modo de pensar através de imagens. O método corresponde a uma abordagem fenomenológica e interpretativa baseada na análise do discurso das pessoas e do Memorial José Avelino, criado num lugar de memória da saúde, marcado por experiências dolorosas. Propõe-se uma reflexão sobre a preservação e a transmissão de memórias dolorosas e a manifestação da memória por meio de imagens mentais ou "objetuais". As imagens não falam por si, mas possuem o potencial de colocar as memórias em movimento e de fazer circular suas informações. Contudo, é necessário um exercício ético-moral, situado entre empatia e imaginação, que conecte o testemunho em primeira pessoa, possibilitado pela história oral, e a "pensatividade das imagens" (SAMAIN 2012).

PALAVRAS-CHAVE: Monumentos e memoriais; Patrimônio Cultural; Memória traumática; Sofrimento; Fotografia.

\section{Memorial José Avelino: a place of memory to light invisible memories}

\section{ABSTRACT}

This study is the result of reflections in the field of memory and heritage, following a course of multidisciplinary studies on heritage processes and receiving direct influence of the fields of history and visual anthropology. Photography is understood as a method and object of study, but mainly as a way of thinking through images. The method corresponds to a phenomenological and interpretative approach based on discourse analysis from the people and the Memorial José Avelino, created in a place of health memory, marked by painful experiences. This study proposes a reflection on the preservation and transmission of painful memories and the expression of the memory through mental or "objectual" images. The pictures do not speak for themselves, but they have the potential to keep memories moving as well as circulate their information. However, a moral ethical exercise is necessary, situated between empathy and imagination that connects the testimony in first person, made possible by Oral History, and the thinking of the images.

KEYWORDS: Monuments and memorials; Cultural heritage; Traumatic memory; suffering; Photography.

Recebido em: 28/02/2016

Aprovado em: 09/11/2016 